\title{
South-South Cooperation 3.0? Managing the consequences of success in the decade ahead
}

\section{Emma Mawdsley}

\begin{abstract}
Perhaps the most significant trend in international development over the last 15 years has been the remarkable expansion of South-South Cooperation (SSC). This paper examines the consequences of the sea change in SSC from around the early millennium, when many Southern states began to expand their development partnerships and activities. The paper constructs a specific periodisation for the analytical purposes of the argument, proposing a heuristic in which 'SSC 1.0' ran from the 1950s to the early 2000s. During these decades, two shared features of otherwise varied contexts, programmes and actors were their relatively small size, as well as their relative neglect and marginalisation by the 'mainstream' international development community and its critics. 'SSC 2.0' refers to the period of remarkable expansion from the early 2000 s to the present. The emergence of 'SSC 3.0', I suggest, is currently revealed by a discernible set of shifts driven in large part by the expansionary successes of SSC 2.0, as well as other turns in the global political economy. Three contemporary trends are identified: cooperation narratives that are increasingly 'muscular', nationalistic and pragmatic; difficulties sustaining claims to 'non-interference' in partner countries; and the further erosion of ideational and operational distinctiveness.
\end{abstract}

\section{Keywords}

South-South Cooperation; global political economy; China; India; Brazil

\section{Introduction}

South-South Cooperation (SSC) is term that is capacious, variegated and flexible. Very broadly, it refers to the transfer and exchange of resources, technology and knowledge, set within claims to shared colonial and post-colonial experiences and identities, and anchored within a wider framework of promoting the collective strength and development of the global South (Prashad 2007; Six 2009; Mawdsley 2012; UNDP 2013; Bergamaschi et al. 2017). In 


\title{
Emma Mawdsley
}

\begin{abstract}
Perhaps the most significant trend in international development over the last 15 years has been the remarkable expansion of South-South Cooperation (SSC). This paper examines the consequences of the sea change in SSC from around the early millennium, when many Southern states began to expand their development partnerships and activities. The paper constructs a specific periodisation for the analytical purposes of the argument, proposing a heuristic in which 'SSC 1.0' ran from the 1950s to the early 2000s. During these decades, two shared features of otherwise varied contexts, programmes and actors were their relatively small size, as well as their relative neglect and marginalisation by the 'mainstream' international development community and its critics. 'SSC 2.0 ' refers to the period of remarkable expansion from the early 2000 s to the present. The emergence of 'SSC 3.0', I suggest, is currently revealed by a discernible set of shifts driven in large part by the expansionary successes of SSC 2.0, as well as other turns in the global political economy. Three contemporary trends are identified: cooperation narratives that are increasingly 'muscular', nationalistic and pragmatic; difficulties sustaining claims to 'non-interference' in partner countries; and the further erosion of ideational and operational distinctiveness.
\end{abstract}

\section{Keywords}

South-South Cooperation; global political economy; China; India; Brazil

\section{Introduction}

South-South Cooperation (SSC) is term that is capacious, variegated and flexible. Very broadly, it refers to the transfer and exchange of resources, technology and knowledge, set within claims to shared colonial and post-colonial experiences and identities, and anchored within a wider framework of promoting the collective strength and development of the global South (Prashad 2007; Six 2009; Mawdsley 2012; UNDP 2013; Bergamaschi et al. 2017). In this paper, I set out a particular periodisation of SSC for the specific analytical purposes of the argument that follows. 'SSC 1.0' refers to the decades from the early 1950 s to the late 
1990s/early 2000s, during which time, whatever the temporal and spatial variations of SSC, it tended to be couched in Third World-ist claims, was relatively less powerful as a geostrategic tool, and was largely neglected by mainstream and critical theorists of international development. 'SSC 2.0' refers to the late 1990s/early 2000s until about 2015, a period in which, by any metric, SSC could be said to have boomed - in resource, visibility, ideational legitimacy and so on. This paper makes the case that the successes of the expansionary phase of SSC 2.0 are now resulting in shifts in narratives, modalities and institutions. Emerging trends suggest that, in the coming decade, SSC will be (a) characterised by a more 'muscular', pragmatic, outcome-oriented narrative framing of economic diplomacy than at present; (b) find more difficulty in maintaining claims to non-interference; and (c) Southern partners will show less ideational and operational distinction from (so-called) 'established' donors, something also being shaped by movement from 'North to South' (Li \& Carey 2014; Janus et al. 2015; Kragelund 2015; Mawdsley 2018). The implications of these changes will be highly varied, as discussed below.

SSC has moved from being the niche topic of a few far-sighted and specialist scholars (e.g. Folke et al 1993; Bräutigam 1998), to being of substantial interest in several academic disciplines and to policy and political establishments globally. While critical scholars have generally been attentive to the importance of the histories of SSC, it is salient that most research and theorising has taken place since the early 2000s, the expansionary period of SSC 2.0. The wider context has been one of proliferating development actors of all sorts, including other (so-called) 'non-traditional' donors like Arab and Central and East European countries, philanthrocapitalist foundations, peer lending platforms, regional banks and institutions, and the growing centrality of the private sector (Banks \& Hulme 2014; Richey \& Ponte 2014; McGoey 2014). Over this period, (so-called) 'established' bilateral donors and multilateral organisations increased their foreign aid contributions, organised in part around the Millennium Development Goals, and engaged in a series of international meetings and agreements to make aid more 'effective', codified in the 2005 Paris Declaration and its subsequent iterations (Hulme \& Fukuda-Parr 2009). The 'mainstream' development community is also currently in a period of dynamic change for a variety of reasons (including the 'rise of the South') (see further below, and also, Eyben 2013; Mawdsley 2015; Kragelund 2015). 
Initial SSC commentary in the post-2000s period, from academics, media, and foreign affairs and development policy communities was varied, with some offering a measured 'establishment,' analysis (e.g. Manning 2006). Other early commentaries reflected poor and parochial understanding of SSC, and occasionally outright hostility based on various shades of prejudice and ideological rivalry (e.g. Hitchens 2008; Naím 2009). Over the following years, analysis advanced with deepening research and interaction, although orthodox commentators often retained implicit and explicit bias around self-regarding yardsticks of the 'North' as the arbiter of 'responsible' development ethics and approaches. Increasing country-specific and field-based research has done much to advance critical, variegated knowledge (e.g. Carmody 2009; Gonzalez-Vicente 2012; Power 2015; Amanor \& Chichava 2016; Taela 2016). Southern analysts, sometimes in transnational dialogue and collaborations, have notably enhanced the depth and sophistication of the field. ${ }^{1}$ The outcomes are inevitably varied. SSC is a complex, porous and multidimensional phenomenon, highly diversified in terms of countries, sectors and activities (Fejerskov et al. 2016). Analysts come from different disciplines. Research topics range widely, from the impacts of training and scholarships, to agri-business investment, to influences on political incumbency, to implications for global development governance, and so on (e.g. Carmody 2011; Cheru 2016; Tugendhat \& Alemu 2016). Constructivist IR, critical development studies, and ethnography have all explored and deconstructed the symbolic and discursive claims of SSC practices and partners. In examining these, and the material flows and practices of SSC, researchers deploy different theoretical frameworks, including gift theory, Marxism, dependency theory, political economy, and institutionalist theory (e.g. Mawdsley 2012; Taylor 2016; van der Merwe 2016).

Notwithstanding this diversity, the vast majority of analysis and theorisation is coloured by the remarkable boom in SSC over the last 15 years or so. Critical questions have been raised throughout; while contextualised by notable headline growth in many parts of the global South - from the B(R)ICS to 'Africa rising' - queries have been raised over GDP figures obscuring more mixed distributional outcomes (Kanbur \& Sumner 2012). A second question is whether this growth has translated into structural and sustainable transformation or just into new forms of dependency and indebtedness (Taylor 2016). But, from about the 2010s

\footnotetext{
${ }^{1}$ See for example, Cheru \& Obi 2010; Chaturvedi et al. 2012; Li et al 2012; Tang et al. 2015; Constantine et al. 2016; Scoones et al. 2016; Shankland \& Gonçalves 2016; Xu et al. 2016; Bergamaschi et al. 2017; Lixia et al. 2018.
} 
onwards (the date differs for different countries depending on the interplay of their domestic economies and politics with international circumstances), a chillier wind began to blow. The most recent commodities super cycle ${ }^{2}$ has faded (Erten \& Ocampo 2013), and other effects of the US-induced global financial crisis are rippling out to the 'periphery' (Kucera et al 2012; Nayyar 2016). These have amplified domestic political and economic vulnerabilities in the global South in both larger and smaller economies. ${ }^{3}$ These factors are certainly influential in shaping SSC now and for the decade ahead, and are invoked in the analysis that follows. However, I suggest that current changes are also an outcome of the very successes of SSC over the last decade or so, particularly for the larger Southern states.

Finally, a note on the use of ' 1.0 ' to ' 3.0 '. There are always dangers in using these simplified devices. To be absolutely clear and to reiterate: I do not suggest that this periodisation provides a chronology of SSC, whether in general or in relation to specific Southern partners. Rather, it is one very particular analytical framework that centres on visibility and influence, based within changing global geoeconomic structures. This particular analytical framing opens up the core question for the paper: what are the implications of a long-standing phenomenon like SSC moving through a phase of rapid expansion?

\section{From SSC 1.0 to SSC 2.0}

This section examines three trends that have accompanied the successful growth and projection of SSC. They are: the effect of increasing visibility; growth out-stripping capacity; and the eroding traction of 'North' and 'South' identities and agendas.

\subsection{Increasing Visibility}

Some historical South-South initiatives like China's Tazara Railway were large and spectacular (Monson 2011). Others gained kudos through sustained and principled commitments, such as Cuba's transformative health cooperation programmes (Kirk 2015).

\footnotetext{
${ }^{2}$ From c.2000 a whole series of commodities - oil, metals, gems, fuels, chemicals, and so on - rose in price. Causes included demand from the rising economies of the South, and financial speculation. After a sharp downturn in 2008/9, some commodities rose again, but (differential) decline has set in again since around 2013.

${ }^{3}$ While many commentators argue that the global economic downturn helps explain the contraction of Brazilian development cooperation (addressed later in the paper), Gonzalez-Vicente argues that in that in the case of China, by contrast, SSC is one response to the crisis of over-production, and that the global and domestic downturn may in fact prompt increased state-backed investments (Gonzalez-Vicente 2016, pers. comm.). This reminds us of the heterogeneity of SSC, and the importance of nuancing broad arguments like the one set out in this paper, to the specificity of particular actors and contexts.
} 
But, most South-South programmes were more modest in scale, even if symbolically they punched above their weight. SSC initiatives to provide scholarships and technical assistance, for example, appear to have been most visible at either highly localised/individualised or elite/diplomatic levels. Over the 2000s, this began to change. China was most prominent and attracted most early attention, followed by others - although the geography of South-South partnerships is highly varied: China is not always and everywhere the most potent player. A highly visible presidential summitry, and a robust narrative of Southern dignity and mutual advancement accompanied the growth in funds, projects and international presence: thus SSC 2.0 powerfully and effectively evoked the historic Third-Worldist framing of SSC 1.0.4 Now, in this expansionary phase, poorer country partners talked of 'looking east', asserting a geography of trade, investment and geopolitical alliance that would upset the old North-South hierarchies (Large \& Patey 2011). New institutions and summits - IBSA, the BRICS, FOCAC, the IAFS ${ }^{5}$ - were stages for high profile pageantry and promises, catching the energy and confidence that characterised the decade or so of expansionary SSC (UNDP 2013).

Southern partners, however, forfeited the relatively low profile of previous years. To different extents and in different contexts they are now exposed to greater scrutiny by media, political actors, trade unions, NGOs, ordinary citizens and other donors and development partners. Highly visible forms and scales of partnership, such as road and dam building, oil concessions, agri-business, and even humanitarian missions (such as Brazil's lead role in Haiti), can be contentious interventions. They can bring very positive responses, build strong relations, and represent welcome development partnerships, but they have also brought growing criticism and concern. For example, Brazil's flagship programme in Mozambique, ProSAVANA, has been set up as a model of the PRODECER initiative in the Cerrado of Brazil, a massive agricultural modernisation project carried out from the 1970s-90s in collaboration with Japan (which also partners in ProSAVANA). ProSAVANA was launched as part of Brazil's accelerated, high profile relationship-building with many African

\footnotetext{
${ }^{4}$ Here I have simplified: changing economic and geopolitical circumstances in the 1980s led both China and India to retreat from the Bandung/Third World-ist positioning, and move towards a more 'realist' approach to development cooperation. This shift was, however, still contextualised by limited resources, marginalisation by the 'mainstream', and North-South dominance, in continuity with the earlier period of SSC 1.0.

${ }^{5}$ IBSA (a forum comprising India, Brazil, South Africa, created in 2003); the BRICS (Brazil, Russia, India, China and South Africa, the latter joining in 2010 a forum formally constituted in 2009); FOCAC (the Forum for China Africa Cooperation, which has met six times since 2000); and IAFS (the India Africa Forum Summit, which has met three times since 2008.)
} 
countries, especially Portuguese-speaking partners. It aims at modernising agriculture to improve production and productivity in the Nacala Corridor region, provide employment, and build transport links to ensure supply chain connections. ProSAVANA is emblematic of many core SSC claims and objectives. It arose from specific domestic development experience and knowledge; it is narratively constructed as a partnership between countries that share particular histories, legacies, agro-ecologies and challenges; and it enrols a blend of public and private financing and actors, the latter including Odebrecht and Vale, two of Brazil's most prominent MNCs (for excellent analyses, see Shankland \& Gonçalves 2016; Marcondes 2016; and Durán \& Chichava 2017). It also relies on a development ideology of modernist transformation (see Dye 2016a). Nevertheless, ProSAVANA has run into problems. Some of these are to do with shrinking Brazilian public resources (see below), but others are a result of failures to address local Mozambican needs and concerns (Woolford \& Nehring 2016). The language of win-win, solidarity, and shared sacrifice and benefit are contested by Mozambican protestors who argue that ProSAVANA is simply another example of land and resource grabbing, regardless of its South-South credentials (for a fuller discussion, see Shankland \& Gonçalves 2016).

Chinese actors have become particularly visible in many partner countries for various reasons - in many cases with positive reputational outcomes. ${ }^{6}$ Chinese exposure is driven by the scale of investment and activity (from construction companies to small-scale market traders); cultural and behavioural differences (for example, living and working in dormitories, language hurdles); and in some cases, (mis-)perceptions of Chinese power and influence. Amongst some of the more problematic outcomes, Cheng (2016) lists mine workers' riots about poor labour conditions and safety standards in Zambia, construction workers' protests about low wages in Nigeria, and peasant protests for resettlement and compensation in Mauritius and Mozambique (see also Bräutigam 2013; Sautman \& Hairong 2016; Zerba 2014). Questions are raised about the developmental benefits of China's presence, including their use of enclave projects, social equality, income distribution, and environmental sustainability (Luckham 2015; Ray et al 2017). The contradictions and contestations of 'development' have opened China up to criticisms more commonly associated in the past with western donors and companies (Gonzalez-Vicente 2013; Taylor 2016). In the meantime, civil conflicts in Sudan and South Sudan, Libya, Egypt, Nigeria and Cameroon, as well as

\footnotetext{
$6 \mathrm{http}: / / \mathrm{www}$. afrobarometer.org/publications/ad122-chinas-growing-presence-africa-wins-largely-positivepopular-reviews\#.WBIWVRaZoI0.twitter
} 
organised crime in Togo and by Somali pirates, have put growing Chinese populations and investments in increasing danger (Alden \& Large, 2015; Cheng 2016).

Growing SSC visibility and impact has translated into transnational activism in a few cases. Social movements and civil society activists have come together to campaign around the shared experiences of being the disposable victims of corporate accumulation strategies, or being under-compensated for losses of lands, ecosystems and livelihoods. Land rights activists in India and Ethiopia, for example, have sought to create common platforms, recognising their shared experiences of land grabbing by the same resource and agribusiness companies across borders (Rowden 2011). Independent Brazilian journalists have visited Angola to work with media organisations there to expose exploitative and corrupt practises of the BNDES and construction companies like Odebrecht in both countries. But examples are limited, with many hindrances to South-South oriented activism, including the lack of legal recourse open to poorer people in many countries (Rodrigues 2016 ). ${ }^{7}$ As the wealthier sections in Cambodia, China, Ethiopia, Fiji and elsewhere do well while large sections languish absolutely or relatively, the transnationally marginalised question the statist projections of win-win and presidential declarations of Southern solidarities.

A growing SSC footprint has also led to greater exposure to the domestic audiences of providers. Given high levels of poverty and/or unmet aspiration, this can lead to considerable criticism, although studies from China (Cheng \& Smyth 2016) and India (Mawdsley 2014) nuance this picture. The narrative framing of SSC has always been about mutual benefits diplomatically and economically in particular. This is somewhat easier for governments to defend compared to dominant western public views of altruistically inspired foreign aid, especially when allied to an inspirational discourse of solidarity to contest global injustice and marginalisation. Wealthier domestic constituencies may welcome the prestige and material opportunities that various initiatives and investments may bring. For the most part it seems that domestic public appraisal and critique has not been a decisive factor influencing elite SSC 2.0 decision-making in most Southern states (Brazil is a partial exception: Cabral 2016). However, there are signs of this changing. One recent instance has been the change in scrutiny of the Indian EXIM Bank process of giving Lines of Credit (explained in more detail below), which came under pressure after an investigative report exposed their concentration towards

\footnotetext{
${ }^{7}$ Details available at Publica http://apublica.org/assunto/especial-africa/
} 
previously unheard of companies, right before the 2015 India-Africa Forum Conference in Delhi. The media story, combined with some unfavourable feedback from a number of African states, created public and parliamentary pressure for greater transparency and accountability (Dye 2016b; Mitra 2017). Southern partners are hardly alone in some of these problems. The long-standing deficiencies of Northern aid and development projects, the creative destruction of capitalist expansion, and the impacts of competing commercial and geopolitical agendas, are widely recognised by critical scholars (Rist 1997; Mosse 2005). Growing exposure during SSC 2.0 of these well attested challenges of planning and implementing any form of development intervention have perhaps knocked earlier confidence in the superiority of South-South knowledge and capacity.

In sum, the growing footprint of many Southern partners around the world has led to greater exposure and visibility. Complications, tensions and misalignments can result from any form of deepened interaction in arenas ranging from geopolitical alliances, to trade, to inherently complicated agricultural projects, and interpersonal relations. Although hugely diverse in form, scale, context and outcome, the common experience of expansion has brought challenges that place new demands on SSC actors, institutions, practices and framings.

\subsection{Growth out-stripping capacity}

The second, related, consequence of success has been the over-extension of finances, programmes and promises, sometimes in the context of limited experience, weak institutional oversight, and competing commercial-political rationales (e.g. Chen 2016). India's Lines of Credit (LOCs), mentioned above, are one example. LOCs are a form of concessional financing, now managed by the EXIM Bank, with their concessional element achieved through subsidies from the Ministry of Commerce. The intent is that partner countries, firms or municipalities identify particular investment propositions to the Indian government (via country High Commissions) to secure a LOC. Borrowers have to spend a minimum of $75 \%$ of the loan on Indian goods and services. In theory this is win-win: capital-short countries, local governments and firms can access concessional finance, and India wins goodwill, sales of goods and services at competitive prices for the buyer, as well as eventual repayment of the LOC. India has rapidly expanded its LOC programme over the last decade, including in South Asia and Africa (Saxena 2016). Indian LOCs have financed a tractor assembly unit in Mali, railway rolling stock upgrades in Angola, a hydro-electric dam in Rwanda, and much more besides. However, concern has emerged about the robustness of some LOCs, some of 
which are starting to look like very bad debts indeed. In part, this has come about through scaling up without sufficient prior-information, monitoring or safeguards. For instance, many of the Indian companies implementing these LOCs had little experience of working outside of India (e.g. BHEL), or were relatively new firms taking advantage of this economic niche without significant engineering expertise, such as Angelique OVI (Dye 2016b). Another issue, as explained by a civil servant in the Ministry of Commerce in 2014, has been competition between economic and political imperatives. He described cases where economic advisers were not convinced of the viability of particular LOC proposals, but were lent on by powerful figures with vested political or financial interests. The question of whether SSC is intended primarily to serve political-diplomatic or economic purposes is in some cases unclear, or in conflict. ${ }^{8}$ The Indian Ministry of External Affairs is now substantially tightening up procedures for LOCs, with technical assistance from the UK's Department for International Development, to which we will return below.

China faces even greater exposure. A recent report calculates that outstanding loans from the two big Chinese policy banks and 13 regional funds are well in excess of the $\$ 700 \mathrm{bn}$ owed to equivalent western-backed institutions. Kynge and Wildau (2015) argue that China now faces worrying exposure to bad debts, brought about at least in part from insufficient diligence and lax lending under conditions of strong political incentives to extend credit to Southern partners. ${ }^{9}$ The response that they and others observe is a more cautious approach to lending. Drawing on examples from Sri Lanka, Ukraine, Venezuela and elsewhere, Kygne and Wildau suggest:

The change in China's financial diplomacy model has implications for the wider world. There are signs that Beijing is growing less tolerant of the more egregious risks, a trend that could deprive some of the world's most fragile economies of crucial lines of credit. Beijing also appears intent on spreading its risk, embracing a more institutional and multilateral approach - as demonstrated by its plans for an Asian Infrastructure Investment Bank and the New Development Bank.

\footnotetext{
${ }^{8}$ In discussion, during a workshop in Delhi. Confidentiality means I cannot provide more details.

${ }^{9} \mathrm{https}: / / \mathrm{www} . \mathrm{ft} . c 0 \mathrm{~m} /$ content/2bb4028a-cbf0-11e4-aeb500144feab7de?siteedition=intl\#axzz3Ukv4ACQO. Last accessed 2 November 2016.
} 
As suggested in second part of the quote, SSC institutions - which usually comprise an assemblage of line and central Ministries, government agencies, think tanks, banks, and so on - have struggled in many cases to keep pace with the diplomatic and commercial energy of SSC over the last decade or so. For example, after a flamboyant period of increase under Lula, Brazilian development cooperation took a lower profile and contracted under Rousseff (Leite et al. 2016; Suyama et al 2016). Most analysts frame this as the result of growing economic pressures in Brazil and/or Rousseff's personal agenda and inclinations, which were less strongly oriented towards foreign policy. However, a third (complementary) explanation is that, in part, Brazilian SSC has struggled to weather changes because of weak institutionalisation under Lula. Falling behind the rapid expansion of partnerships, programmes and financing were the necessary regulatory changes, sufficient monitoring and oversight, personnel training, and more resilient financing structures (Marcondes \& Mawdsley 2017). The Brazilian Development Bank (BNDES), for example, which is the major source of corporate financing for Brazilian companies in Africa, has changed leadership and is signalling a retreat from large loan disbursements for international projects. In September 2016, Michel Temer, who ousted Rousseff, announced the closure of the Department for Humanitarian Cooperation and Combat Against Hunger (CGFOME). This had been a flagship programme under Lula, created in 2004 to combat food security issues in Brazil and beyond. As Fiori (2016) charts out, this programme was one part of an ambitious and often effective foreign policy agenda to shape global norms and institutions to better reflect on and respond to the South. Its part in domestic and international contributions to various aspects of food security, from humanitarian aid to longer term social protection programmes, has been praised across the world. Temer signalled that SSC would take a lower profile under his leadership, and that he intended to accelerate fiscal contraction (initiated by Rousseff) and return a stronger northern orientation to Brazilian diplomacy (something President Bolsonaro looks likely to accelerate). However, while these cuts can be attributed to a political swing, it is also worth noting that for all of its widely celebrated high profile, even under Lula CGFOME was a rather marginalized division within the Ministry, with only one diplomat working there. Rondó was never promoted to ambassadorial ranking and was not given additional diplomatic staff. Relations with the Brazilian Cooperation Agency (ABC) were never clearly established, and sometimes tense. Most of the work that CGFOME was doing was related to donations of food for countries facing conflict or natural disaster, but these had to be negotiated almost on a case-by-case basis since the existing Brazilian legislation did not enable this practice (Marcondes 2016). The reputation of GCFOME 
exceeded its institutional and regulatory anchoring, making it vulnerable to a shift in foreign policy priorities.

\subsection{Eroding 'North' and 'South' identities and agendas}

Finally, SSC partners look like they will find it harder in coming years to hold onto the distinctive ideational space that many have insistently projected between themselves and the donors of the OECD-DAC. While they were largely successful in resisting efforts at cooption during SSC 2.0 (Abdenur \& Da Fonseca 2013), greater activity, dialogue and interaction is promoting a degree of institutional isomorphism, and convergence around particular ideas, languages and frameworks (Li \& Carey 2014; Kragelund 2015; Fejerskov et al. 2016). DAC donors, individually and collectively, have actively and strategically sought to build relations with Southern partners, and in different ways, to different extents, and with varied agendas, many Southern partners are engaging in dialogue, cooperation and collaboration. Examples include trilateral development cooperation (McEwan \& Mawdsley 2012), the China-DAC Study Group (Stahl 2013), and various UN funds, programmes and agencies. Istanbul, for example, now hosts one of UNDP's six global policy centres, the Istanbul International Centre for Private Sector in Development (established in 2011); the UNDP has a Private Sector and Foundations Team; and there are regional centres for UNFPA, UNDP and UN Women (opened between 2011 and 2015: Haug 2016). In India, one of the new directions taken up by the UK's Department for International Development (DFID) following the decision to withdraw from 'traditional' financial aid provision from 2015, has been to promote a 'global partnership' with India, finding ways of working together to promote growth and poverty reduction in third countries (Paulo 2018). DFID is now advising the EXIM Bank on negotiating and monitoring its Lines of Credit. ${ }^{10}$ Elsewhere, apparently very different development partners have found themselves confronting similar issues and constraints, leading to similarities in outcomes, or indeed, specific collaborations. For example, Curtis (2013) finds that Chinese interests in the Democratic Republic of Congo have increasingly coincided with evolving Western interests in support of stabilization and market-driven economic activities (an approach, she goes on to argue, which is flawed).

The case of the Asian Infrastructure Investment Bank (AIIB) is instructive. In the face of explicit opposition from the USA, a number of western countries joined the Board, something

\footnotetext{
${ }^{10}$ Author's interviews with Delhi-based DFID staff, October 2016.
} 
that points to shrinking ideational distance, expanding sites of collaboration and cooperation, and intertwined material flows and practices. In 2016, the World Bank and New Development Bank (formerly the BRICS Development Bank) announced a deal for cofinancing of projects, facilitation of knowledge exchange, advisory services, secondment and staff exchanges. ${ }^{11}$ Poorer countries may find themselves at odds with their increasingly powerful 'representatives', while larger/stronger Southern partners may find it increasingly hard to sustain a claim to a shared 'developing country' identity (Nel \& Taylor 2013), or present themselves as champions contesting the inequalities of global neoliberal capitalism (Gray \& Gills 2016).

The blurring of the ideational divide between 'North-South' aid hierarchies and 'SouthSouth' development cooperation is not just because of movement on the part of the SSC providers, but also due to shifts amongst the 'established' donors. Chaturvedi (2016, pers. comm.) has described this as the 'Southernisation of ODA' (Mawdsley 2018). A key trend within most DAC donors is the (re-)installation of 'economic growth' as the central analytic of development. Poverty reduction and social welfare are certainly invoked, but the discursive buzz is now all about jobs, economic growth and infrastructure. The private sector is placed firmly at the heart of this agenda, often through state-capital hybrids like PublicPrivate Partnerships (PPPs), which act to socialise costs and risks while privatising profits. Central to this is the unravelling of Overseas Development Assistance (ODA, or 'foreign aid') by the OECD-DAC. Instead, a world 'beyond aid' is being invoked (Severino \& Ray 2009; Janus et al. 2015), in which new blurred and blended forms of 'development finance' will supposedly be leveraged to provide the necessary billions needed to fund global development (Collier 2013; Schmitd-Traub 2015). These instruments and approaches - for better and worse - bear considerable similarities to those used by the Southern partners, many of which reject the concept of 'aid' to embrace a more blended conceptualisation of development finance.

This section has made a case for seeing in the expansionary successes of SSC 2.0 some of the seeds of change. First, greater visibility at home and abroad has brought greater scrutiny. While in some cases this has enhanced the reputation and status of the development partner,

\footnotetext{
11 http://www.worldbank.org/en/news/press-release/2016/09/09/world-bank-group-new-development-bank-laygroundwork-for-cooperation
} 
it has also brought criticism and protest. Second, institutions, regulatory frameworks and the provision of experienced and skilled personnel have struggled to keep up with the rapid expansion of SSC over the last decade or so. And third, SSC partners now find themselves projecting development narratives and identities in a more complex international landscape, in which their ideational claims - for example, to mutual benefit, shared experiences and knowledges, and common cause with poorer nations - are more open to question, contest and even mimicry by 'Northern' donors and Southern partners. In a variety of ways then, the languages, practices and institutions inherited from the second half of the twentieth century, or SSC 1.0, and strongly projected through the period of expansion, SSC 2.0, are now losing some of their fitness for purpose. In the next section, I identify three emerging trends in the formation of 'SSC 3.0'.

\section{The decade ahead: SSC 3.0}

Clearly delineated step change does not take place in the case of a complex and variegated phenomenon like SSC. While I suggest that a new phase of SSC is emerging, it should be obvious that I am not proposing some sort of universal transition from one coherent mode to another. Precursors of most of the issues and trends described above can be traced back some years; and changes are differentiated across the very diverse terrain of SSC. Nevertheless, there is sufficient critical mass in the shifts in narratives and practices within and across SSC to support the idea of an emerging third phase. Three trends are identified here. The first is a more pragmatic turn in SSC discourse, with less of the affective framing so characteristic of earlier and existing narratives, and more discursive focus on outcomes and effectiveness for the provider as well as the partner. The second is greater attentiveness to the difficulties and challenges of working within partner countries, sometimes in ways that clearly (further) compromise claims to non-interference. Finally, Southern partners of all sorts may find it more difficult to project ideational and operational differences in terms of a North-South binary, given growing forms of cooperation, and the convergence of some agendas and interests.

\subsection{A turn towards a less affective discursive framing.}

SSC has long had a strong pragmatic rationality, entailing the explicit pursuit of provider interests and agendas as a part of the claim to mutually beneficial outcomes. These have been framed within powerful discourses of empathy and solidarity, shaped by Third World-ist, 
socialist, non-aligned and colonial/post-colonial positionalities (Chacko 2012). The construction of 'win-win' South-South development partnerships in circumstances of shared poverty and geopolitical marginalisation enabled the stitching together of an attractive claim to a specific moral purpose while achieving joint economic and diplomatic advancement (Chan 2013). While this affective framing will continue to be deployed and have resonance, there is evidence of a move towards a stronger pragmatic framing as well as practice of SSC. In 2011, for example, after a few months in office, Dilma Rousseff instructed the Brazilian Foreign Minister that she was interested in 'results-oriented diplomacy', with more concrete achievements and 'less symbolism'. ${ }^{12}$ In 2014, the presidential instruction regarding foreign relations was to emphasize the role of commercial promotion in Brazilian diplomatic relations. ${ }^{13}$ In his inaugural speech on 18 May 2016, President Temer's new Foreign Affairs Minister, Serra, indicated his intention to drive a more economically rewarding set of relations, and (notwithstanding the change in direction under Rousseff, noted above), took a swipe at the previous Worker's Party (PT) administrations:

Contrary to what was promoted [by Lula and Rousseff], modern Africa does not ask for sympathy but hopes for an effective technological and investment exchange. Pragmatic solidarity towards countries of the global South will continue to be an important strategy of Brazilian foreign policy. This is the right South-South strategy and not the one that was practiced with publicity purposes with low economic benefits and high diplomatic investments. ${ }^{14}$

Needless to say, these trends and transitions are heavily contextually nuanced, as Sumaya et al (2016) demonstrate in their discussion of the continuities and shifts between the LulaRousseff-Temer regimes. But, while recognising such complexity, this appears to be a generalizable trend across many SSC partners. India is at least partly signalling a shift in tone in framing its development cooperation. Vittorini (2015) has observed less of the traditional South-South rhetoric by Prime Minister Modi, elected in 2014, possibly put off by its association with the cadences of Nehruvian foreign policy. Modi missed the $60^{\text {th }}$ anniversary meeting of the Bandung Conference in 2015, and delayed the start of the third India Africa

\footnotetext{
12 Natuza Nery 'Dilma cobra do Itamaraty diplomacia de resultados' Folha de São Paulo, 28 March, 2011.

${ }^{13}$ Lisandra Paraguassu “ Itamaraty terá novo 'vendedor' do Brasil” O Estado de São Paulo, 15 December 2014.

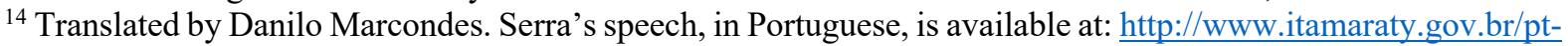
BR/discursos-artigos-e-entrevistas-categoria/ministro-das-relacoes-exteriores-discursos/14038-discurso-doministro-jose-serra-por-ocasiao-da-cerimonia-de-transmissao-do-cargo-de-ministro-de-estado-das-relacoesexteriores-brasilia-18-de-maio-de-2016
} 
Forum Summit to 2015. Modi's trademark insistence on an uncompromising agenda of economic growth may also play out in a more pragmatist flavour to Indian development cooperation (Dye 2016b). Analysts from the Observer Research Foundation, an influential Delhi think tank, argue for a more 'robust' Indian development cooperation policy that supports its wider foreign policy ambitions of taking on a leading global role (Aneja \& Ngangom 2017). Illuminating the argument made here nicely, they argue for a shift in the ethical principles that they suggest should now underpin Indian development partnerships. Arguing for a move away from Nehruvian language and politics (in this schema, we could say the language of SSC 1.0, which carried over into SSC 2.0), they state:

... the ethical mooring of India's development partnerships need not lie in lofty moral principles rooted in broader world views, but instead may be derived from sustaining legitimate and accountable processes. In other words, a sustainable ethical mooring ... might be derived from a pragmatic lens of delivering programmes that have value for money, and are delivered through effective, transparent and accountable delivery mechanisms. (p.6) $)^{15}$

Jain and Marcondes (2017) also observe this shift, noting that "the rhetoric and ideological prominence of socialism and non-alignment has somewhat faded in practice ... as India has increasingly developed economically and embraced the rules of neoliberal globalisation" (p.39). In the case of Indonesia, which uses the term South-South Technical Cooperation (SSTC), Boisjolie (2014, p. 48) observes that:

... such relations are being increasingly framed in terms of the direct benefits that they can bring to Indonesia ... respondents disclosed that SSTC follows an "Indonesia first" policy designed to complement domestic development policies, and that projects are increasingly scrutinised on a 'what's in it for us?' basis.

China certainly provides strong evidence of a more cautious narrative accompanying more cautious practices. Kynge and Wildau (2015) report a Chinese official with the influential National Development and Reform Commission - the government ministry responsible for

\footnotetext{
15 The implication that SSC under Nehru did not achieve 'value for money', and that 'lofty principles' cannot simultaneously be pragmatic, are open to contest (Chako 2012).
} 
economic planning - saying that frustration is mounting in Beijing over poor returns from unsatisfactory projects, and a sense that state lenders have in the past taken on too much risk in unstable countries.

China had no choice but to lend a lot to risky countries because they had the commodities we needed and because the western multilateral organisations already dominated the rest of the world," the official says. "These days we need viable projects and a good return. We don't want to back losers."

The point is not that many of these 'realist' directions in foreign policy and SSC are new (see for example, footnote 4, on the 'realist' turn of Indian and Chinese cooperation in the 1980s), but that the earlier rhetoric and narrative framing of SSC 1.0 and 2.0 is now shifting, largely because of the successful expansion of the last 10-15 years. Grand claims to brotherhood and shared understanding are harder to sustain as relationships deepen, and (inevitably), frictions and problems emerge or are more exposed (e.g. Adhikari 2014); and as the larger Southern powers have grown far faster than most smaller states, with implications for their interests and exercise of power within global rule making. The recent expansion of SSC has seen warm partnerships created and fostered, and development interventions and investments have helped build infrastructure, raise productivity and create jobs. Enhanced trade has provided cheap consumer goods and stimulated investment. Health, education and skill development have been enhanced. In an 'age of choice', smaller and poorer states have been empowered in an opening market place of partners, finances and ideas (Mohan \& Lampert 2013; Greenhill et al 2013). But South-South Cooperation has also met its growing share of challenges. These include the consequences of rapid expansion in sometimes unfamiliar environs; weak, unstable and/or corrupt partner governments; and the realities of complex development challenges, which turn out to be not quite so tractable as perhaps initially reasoned. Cultural misunderstandings and prejudices (on all sides) have sometimes had deleterious effects (Modi \& D'Silva 2016). Large-scale investments and interventions have created losers as well as winners, provoking anger and protest in some quarters. Machines break down, plans falter, roads crumble, new crop technologies are inappropriate - aspirations and ambitions can start to erode. Non-capitalist lives, economies and cultures have, to date, little place within different official Southern conceptualisations of development (Rowden 2011; Gudynas 2016). Southern investments and interventions have been caught up in criminal enterprises, social unrest and civil wars. Turkish police trainers, development workers and 
business people in Somalia, for example, have been targeted by Al-Shabaab, which accuses Turkey of supporting secular and non-Islamic structures (Ozkan 2017). One response to these sorts of challenges is to take a more interventionist approach, which is explored next.

\subsection{Eroding 'non-interference'}

As well as greater caution and even retreat, an outcome of these tougher exposures and deepening investments are signs of a more interventionist stance, compromising muchvaunted claims to non-interference in sovereign matters inherited from the first decades of SSC, and proudly asserted through its more recent expansionary phase. This is the second emerging trend of SSC 3.0. Perceptions of the quality of SSC matters to building diplomatic alliances, for the success of long term economic relations and corporations' reputations and, if they are to be justified to domestic audiences. This means that whereas in the past the claims of SSC perhaps had more significance, now outcomes have become important in themselves, and to secure the strategic interests. For example, in the case of Indian LOCs, raised above, Dye (2016b) finds that:

India seems to be adopting a more interventionist, stringent, and one could even say conditions-laden, export-credit process. While not micromanaging projects in the way the World Bank does, or demanding environmental and social assessments that can theoretically bar a project, they certainly are establishing a more hands-on regime.

This is particularly clear in the case of China - although, as a number of commentators have expertly dissected, 'non-interference' has always been more conceptually and politically compromised than is asserted (Large 2008; Pang 2013; Verhoeven 2014; Gonzalez-Vicente 2015). A study by Cheng (2016) on the evolving content of the FOCAC outcome statements (2000-2015) and the China-Africa White Papers (2006, 2010 and 2013) reveals the evolution from the promotion of bilateral trade and investment in areas such as agriculture, infrastructure, and industry, towards far more detailed and closer proposals for integrating trade and production. For example, the 2012 FOCAC Action Plan included new areas of cooperation in "customs, taxation, inspection and quarantine, standards, as well as verification and certification", more specifically, including "inspection, quarantine and supervision of imports and exports, and ... supervision of imports and exports quality and safety, sanitary and phytosanitary regulation and food safety inspection" (FOCAC V Action Plan, 4.4.6). Cheng (2016) notes that the 2012 FOCAC Declaration touched for the first time 
upon the trade and industrial policy planning of African countries, opening new areas for much deeper influence. The 2013 China-Africa White Paper reveals another trend - a new language and concern with 'people-centred' development, and the social realm. Like the 2015 FOCAC Declaration, there is much more inclusion of 'the local', poverty reduction and 'human development'. It seems clear that China is increasingly attuned to, and is attempting to pre-empt and offset, criticism and protest of its development partnership and investments (see also, Kragelund 2015). Similarly, the emerging management of India's LOCs is changing from being (in theory) demand driven. Instead of the recipient country deciding alone on projects, there is a growing turn to 'joint thinking' on sectors for intervention, with the Indian government then taking a lead in providing the range of its support in infrastructure financing, education and training. The potential sectors envisioned in such collaboration would be limited to those India itself has expertise in, signalling a substantive shift from the earlier blank-slate of possibilities.

In many places, SSC is being institutionally consolidated following on from the recent period of heady expansion (Sidiropolos et al 2015). In different ways and at different paces, we see the creation and growth of dedicated development assistance agencies, such as India's Development Partnership Administration, created in 2012; the South African International Development Agency (Besharati 2013); and in 2018, the launch of The China International Development Cooperation Agency. In many countries, SSC is being embedded in newly delineated budget lines, regulatory frameworks, and strengthening institutional homes and networks. Southern think tanks, civil society organisations, policy makers, diplomats and bureaucrats are becoming more familiar and experienced in the language, rationales and conduct of different forms of SSC. All of this means that whatever the intended outcomes of particular policies and interventions are, they may well be better aimed and implemented. This is not the same as saying that they will be more 'developmentally effective', given this is a contested construct. One outcome may be that SSC is a less pliant diplomatic tool, or at least, that details are likely to be worked out with more expertise and precision than in some previous cases.

\subsection{Difficulty in projecting differences as a North-South binary}

Finally, as a number of commentators suggest, there is considerable evidence of convergence between donors and development partners of all hues (Li \& Carey 2014; Kragelund 2015; Fejerskov et al 2016). This is not to say that substantive differences in agendas, interests, 
modalities, cultures and styles will not persist - they do and will. But, in various registers, sites and scales, it is clear that the construct of a DAC/non-DAC binary - to the extent that it was ever accurate - is no longer really sustainable. Uneven power hierarchies continue to influence and shape the realm of international development and humanitarianism, but the terrain is far more polycentric than ever before (Horner \& Hulme 2017). This partial convergence may lead to improved coordination and productive collaborations in some contexts, but also reduce the policy space that appeared to open up for poorer partners in the previous decade.

\section{Conclusions}

South-South Cooperation is here to stay, notwithstanding turbulent times, including the contraction and merging of some programmes and funding for some partners. In this paper, I argue that the last decade or so has been one of considerable 'success' for SSC: materially (increasing resources, finances, institutions), ideationally (the consolidation and influence of Southern development models and ideas) and ontologically (the increasingly secure status and legitimacy of Southern states as development partners). However, these successes have simultaneously created challenges that are resulting in a new set of imperatives and contexts for the decade ahead. Over the last 15 years or so, a rapidly expanding SSC 2.0 has been discursively framed largely in continuity with its origins in SSC 1.0, that is, Third World-ist, socialist and non-aligned positionalities; sometimes living up to these ideals and sometimes diverging in practice, realpolitik and outcomes. The first conclusion is that while proponents of SSC 3.0 certainly will not entirely ditch this attractive narrative framing, it is increasingly hard to sustain at home and abroad. The consequences of the most recent global financial crisis, and the vulnerabilities of many Southern economies, means that some of the earlier language of solidarity is in some contexts not just inaccurate, but a liability. Secondly, the inevitable and inherent complexities of deepening relations and expanding investment means that the larger SSC partners especially, may find it harder to sustain the claim or reality of non-interference: their relationships and investments require deeper and more interventionist approaches. The institutional and regulatory infrastructures around SSC are in some cases catching up with the expansionary phase. This will temper some of the grand gestures, and is likely to reinforce the pragmatic and interventionist trends listed above. Finally, differences, rivalries and competition - economic, ideational and geopolitical - remain evident.

Nonetheless, growing familiarity, shared contexts and interests, institutional deepening and 
collaborations are producing a more complex, multidimensional ecology of development actors, in which simple North/South identities are even less clearly anchored than before. The very ebullience of the last decade or so has changed the terrain, resulting in a new era emerging for South-South Cooperation. 


\section{Bibliography}

Abdenur, A.E. and Da Fonseca, J. 2013: The North's growing role in South-South cooperation: keeping the foothold. Third World Quarterly, 34 (8), 1475-1491.

Adhikari, M. 2014: Politics and perceptions of Indian aid to Nepal. Strategic Analysis, 38 (3), $325-40$.

Alden, C. and Large, D. (2015) 'On becoming a norms maker: Chinese foreign policy, norms evolution and the challenges of security in Africa.' The China Quarterly 221: 123-142.

Amanor, K. S. and Chichava, S. (2016) 'South-south cooperation, agribusiness, and African agricultural development: Brazil and China in Ghana and Mozambique.' World Development 81: 13-23.

Aneja, U. and Ngangom, T. (2017) Learning from the old, preparing for the new: Designing an Institutional Architecture for India's Development Partnerships. ORF Working Paper, March 2017

Banks, N. and Hulme, D. (2014) 'New development alternatives or business as usual with a new face? The transformative potential of new actors and alliances in development.' Third World Quarterly 35(1): 181-195.

Bergamaschi, I., Moore, P. and Tickner, A.B. (eds) (2017) South-South Cooperation Beyond the Myths: Rising Donors, New Aid Practices? Palgrave Macmillan.

Besharati, N.A. (2013) South African Development Partnership Agency (SAPDA): Strategic Aid or Development Packages for Africa? South African Institute of International Affairs Research Report 12, August 2013.

Boisjolie, T.J. (2014) Emerging Development Partners and Aid Governance: Examining the Role of 'Aid Effectiveness' in Indonesia and South Africa. South-South Cooperation. Masters thesis, University of San Diego. Available at: etd9364_TBoisjolie.pdf. Last accessed 7 May 2018. 
Bräutigam, D. (1998) Chinese Aid and African Development: Exporting Green Revolution. London: Macmillan Press.

Bräutigam, D. (2013) 'Nigerian workers protest conditions at Chinese construction projects.' China in Africa The Real Story, February 1, 2013.

http://www.chinaafricarealstory.com/2013/02/nigerian-workers-protest-conditions-at.html

Cabral, L. (2016) Priests, Technicians and Traders: Actors, Interests and Discursive Politics In Brazil's Agricultural Development Cooperation Programmes With Mozambique. PhD Thesis, University of Sussex.

Carmody, P. (2009) 'An Asian-driven economic recovery in Africa? The Zambian case.'

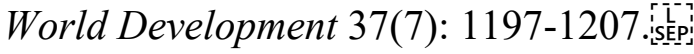

Carmody, P. (2011) The New Scramble for Africa. Cambridge: Polity Press.

Chacko, P. (2012), Indian Foreign Policy: The Politics of Postcolonial Identity from 1947 to 2004. London and New York: Routledge.

Chan, S. (ed.) (2013) The Morality of China in Africa: The Middle Kingdom and the Dark Continent. Zed Books

Chaturvedi, S.; Fues, T. and Sidiropoulos, E. (eds.) 2012: Development cooperation and emerging powers: new partners or old patterns? London: Zed Books.

Chen, T. (2016) 'What happened to China Development Bank’s \$3 billion loan to Ghana?' SAIS-China Africa Research Institute Policy Brief No. 10, Feb 2016. http://www.chinaafricarealstory.com/2016/03/what-happened-to-china-development.html (last accessed August 30, 2016).

Cheng, Z. and Smyth, R. (2016) Why Give it Away When You Need it Yourself? Understanding Public Support for Foreign Aid in China. The Journal of Development Studies, 52, pp. 53-71 
Cheng, H. (2016) FOCAC's 'Double Movement' and the Politics of China-Africa Development Cooperation: A Critical Assessment. Masters dissertation, University of Cambridge.

Cheru, F. (2016) 'Emerging Southern powers and new forms of South-South cooperation: Ethiopia's strategic engagement with China and India.' Third World Quarterly 37(4): 592610.

Cheru, F. and Obi, C. (eds.) (2010) The Rise of China and India in Africa. London and Uppsala. Sweden: Zed and the Nordiska Afrikainstitutet.

Collier P (2013) Aid as catalyst for pioneer investment. UNU-WIDER Research Paper, WP2013/004.

Constantine, J., Bloom, G. and Shankland, A. (2016) Towards Mutual Learning with the Rising Powers. IDS Policy Briefing 123.

Curtis, D. (2013) 'China and the insecurity of development in the Democratic Republic of the Congo (DRC). International Peacekeeping 20(5): 551-569.

Durán, J, and Chichava, S. (2017) Resisting South-South Cooperation? Mozambican Civil Society and Brazilian Agricultural Cooperation. In Bergamaschi, I., Moore, P. and Tickner, A.B. (eds) South-South Cooperation Beyond the Myths: Rising Donors, New Aid Practices? Palgrave Macmillan, pp. 271-300

Dye, B. (2016a) The Return of 'high modernism'? Exploring a changing development paradigm through a Rwandan case study of dam construction. Journal of Eastern African Studies 10 (2), 302-324

Dye, B. (2016b) As India-Africa ties are boosted a shift in this South-South relationship is taking place. Available at: http://blogs.lse.ac.uk/africaatlse/2016/11/09/as-india-africa-tiesare-boosted-a-shift-in-this-south-south-relationship-is-taking-place/ 
Erten, B. and Ocampo, J. (2013) Super Cycles of Commodity Prices Since the Mid-Ninetenth Century. World Development, 44, pp. 14-30

Eyben, R. (2013) 'Building relations in development cooperation: Traditional donors and the rising powers.' Institute of Development Studies Policy Brief 36, May 282013.

Fejerskov, A., Lundsgaarde, E. and Cold-Ravnkilde, S. (2016) Uncovering the dynamics of interaction in development cooperation: a review of the 'new actors in development' research agenda. DIIS Working Paper 2016:1, Copenhagen, Denmark.

Fiori, J. (2016) 'Brazil changes course' DemocraciaAbierta, 11 October. Available at: https://www.opendemocracy.net/democraciaabierta/juliano-fiori/brazil-changes-course

Folke, S., Fold, N. and Enevoldsen, T. (1993) South-South Trade and Development: Manufactures in the New International Division of Labour. Macmillan Press.

Gonzalez-Vicente, R. (2012) 'Mapping Chinese mining investment in Latin America: Politics or market?' The China Quarterly 209: 35-58.

\section{Gonzalez Vicente R. (2013), Development dynamics of Chinese resource-based investment} in Peru and Ecuador, Latin American Politics and Society 55(1): 46-72.

Gonzalez-Vicente, R. (2015) 'The limits to China's non-interference foreign policy: pro-state interventionism and the rescaling of economic governance.' Australian Journal of International Affairs 69(2): 205-223.

Gray, K. and Gills, B.K. (2016) 'South-South cooperation and the rise of the Global South.' Third World Quarterly 37(4): 557-574.

Greenhill, R., Prizzon, A. and Rogerson, A. 2013: The age of choice: how are developing countries managing the new aid landscape? Overseas Development Institute. London.

Gudynas, E. (2016) Beyond varieties of development: disputes and alternatives. Third World Quarterly 37 (4), 721-32. 
Haug, S. (2016) Turkey as a 'Rising Power'? Insights from Global Development Governance. Paper presented at the 2016 International Studies Association (ISA) Annual Convention, Atlanta, Georgia, USA, March 2016.

Hitchins, P. 2008: How China has created a new slave empire in Africa. Mail Online, 28 September 2008. http://www.dailymail.co.uk/news/article-1063198/PETER-HITCHENSHow-China-created-new-slave-empire-Africa.html. Last retrieved 17 July 2015. http://www.ids.ac.uk/publication/building-relationships-in-development-cooperation-tradition al-donors-and-the-rising-powers (last accessed August 30, 2016).

Horner, R. and D. Hulme. (2017). Converging divergence? Unpacking the new geography of 21 st century global development. GDI Working Paper 2017-010. https:// www.gdi.manchester.ac.uk/research/publications/gdi- working-papers/2017010/\#d.en.533170

Hulme, D. and Fukuda-Parr, S. (2009) "International norm dynamics and the 'end of poverty': understanding the Millennium Development Goals”, Brooks World Poverty Institute Working Paper No. 96.

Jain, P. and Marcondes, D. (2017) Malleable Identities and Blurring Frontiers of Cooperation: Reflections from India's “Distinct” Engagement with Senegal and Mozambique. In Bergamaschi, I., Moore, P. and Tickner, A.B. (eds) South-South Cooperation Beyond the Myths: Rising Donors, New Aid Practices? Palgrave Macmillan, pp. $31-58$

Janus, H., Klingebiel, S. and Paulo, S. 2015: Beyond aid: a conceptual perspective of the transformation of development cooperation. Journal of International Development. 27 (2), 155-169.

Kanbur, R. and Sumner, A. 2012: Poor countries or poor people? Development assistance and the new geography of global poverty. Journal of International Development, 24 (6), 68695. 
Kirk, J.M. (2015) Healthcare without Borders: Understanding Cuban Medical Internationalism. University of Florida.

Kragelund, P. (2015) 'Towards convergence and cooperation in the global development finance regime: closing Africa's policy space.' Cambridge Review of International Affairs 28(2): 246-262.

Kucera, D., Roncolato, L. and von Uexkull, E. (2012) Trade Contraction and Employment in India and South Africa during the Global Crisis. World Development, 40 (6): 1122-1134

Kynge, J. and Wildau, G. (2015) China: With Friends Like These. Financial Times, March 17 2015. Available at: https://www.ft.com/content/2bb4028a-cbf0-11e4-aeb5-00144feab7de

Large, D. (2008) 'China \& the Contradictions of 'Non-interference' in Sudan.' Review of African Political Economy 35(115): 93-106.

Large, D. and Patey, L. (eds) (2011) Sudan looks East: China, India and the politics of Asian alternatives. Woodbridge, Suffolk and Rochester, New York: James Curreyistepi

Leite, I.C., Suyama, B., Waisbich, L.T. and Pomeroy, M. (2014) Brazil's Engagement in International Development Cooperation: The State of The Debate. IDS Evidence Report 59.

Li, X and Carey, R. 2014: Rising powers in international development: The BRICS and the international development system: Challenge and convergence?" Institute of Development Studies Evidence Report no.58, March 2014.

Li, X., Qi, G., Tang, L., Zhao, L., Jin, L., Guo, Z. and Wu, J. (2012) Agricultural Development in. China and Africa: A Comparative Analysis. London: Routledge.

Lixia, T., Xiaoyun, L., \& Langton, M. (2018). Blurring the Lines between Aid and Business: An Ethnographic Study of the Chinese Agricultural Technology Demonstration Centre in Zimbabwe. China: An International Journal, 16 (1), 23-44. 
Luckham, R. (2015) 'Whose security? Building inclusive and secure societies in an unequal and insecure world.' Institute for Development Studies. Evidence Report 151.

http://psm.du.edu/media/documents/reports_and_stats/journal_articles/reports_journal_1_lu ckham_inclusive-secure-societies.pdf (last accessed August 30, 2016).

Manning, R. (2006) Will "emerging donors" change the face of international co- operation? Development Policy Review 24(4): 371-385.

Marcondes, D. and Mawdsley, E. (2017) South-South in retreat? Lula-Rousseff-Temer transitions and Brazilian Development Cooperation. International Affairs, 93 (3) 681-99

Marcondes, Danilo (2016) 'Brazilian South-South cooperation in Africa: policy transfers in health and agriculture to Mozambique', $\mathrm{PhD}$ thesis, Department of Politics and International Studies, University of Cambridge.

Mawdsley, E. (2012) From recipients to donors: emerging powers and the changing development landscape. London: Zed Books.

Mawdsley, E. (2014) Public perceptions of India's role as an international development cooperation partner: domestic responses to rising 'donor' visibility. Third World Quarterly 35 (6), 958-79.

Mawdsley, E. (2015) 'Development geography 1 Cooperation, competition and convergence between 'North' and 'South'.' Progress in Human Geography p.0309132515601776.

Mawdsley, E. (2018) The 'Southernisation' of Development. Asia Pacific Viewpoint, 59 (2), 173-85.

McEwan, C., Mawdsley, E. (2012) Trilateral Development Cooperation: Power and Politics in Emerging Aid Relationships' Development and Change 43(6): 1185-1209.

McGoey L 2014 The philanthropic state: market-state hybrids in the philanthrocapitalist turn. Third World Quarterly 35 109-25 
Mitra, D. (2017) India's Aid Diplomacy is worth $\$ 24$ billion. But how well is the money being spent? The Wire, 16 June 2017. Available at https://thewire.in/diplomacy/india-linesof-credit-aid-diplomacy. Last accessed 7 May 2018.

Modi, R. and D’Silva, R. (2015) Liminal Spaces: Racism against Africans in India. Economic and Political Weekly 51 (41), pp. 18-20

Mohan, G. and Lampert, B. (2013) 'Negotiating China: reinserting African agency into China-Africa relations.' African Affairs 112 (446): 92-110.

Monson, J (2011) Africa's Freedom Railway: How a Chinese Development Project Changed Lives and Livelihoods in Tanzania, Bloomington: Indiana University Press.

Mosse, D. (2005) Cultivating Development: An Ethnography of Aid Policy and Practice. Pluto Press.

Naím, M. 2009: "Rogue aid” in Foreign Policy, March/April 95-96. Available at: http://foreignpolicy.com/2009/10/15/rogue-aid/. Last retrieved 17 July 2015.

Nayyar, D. (2016) BRICS, developing countries and global governance. World Development. Third World Quarterly 37 (4), 575-91.

Nel, P., and I. Taylor. "Bugger thy Neighbour? IBSA and South-South Solidarity." Third World Quarterly 34, 6 (2013): 1091-1100: [is

Ozkan, M. (2017) The Turkish Way of Doing Development Aid?: An Analysis from the Somali Laboratory. In Bergamaschi, I., Moore, P. and Tickner, A.B. (eds) South-South Cooperation Beyond the Myths: Rising Donors, New Aid Practices? Palgrave Macmillan, pp. $59-78$.

Pang, Z (2013) The Non-interference Dilemma: Adapting China's Approach to the Context of African and International Realities. In Berhe, MG and Hongwu, L (2013) ChinaAfrica Relations: Governance, Peace and Security. Institute for Peace and Security Studies 
(Addis Ababa University) and Institute of African Studies (Zhejiang Normal University), pp. 46-54.

Paulo, S. (2018) India as a partner in triangular development cooperation: Prospects for the India-UK partnership for global development. Observer Research Foundation Working Paper, March 2018. Available at https://www.orfonline.org/wpcontent/uploads/2018/03/ORF_WorkingPaper_Triangular_Cooperation.pdf. Last accessed 22 August 2018.

Power, M. 2015. Angola 2025: The Future of the "World's Richest Poor Country" as Seen through a Chinese Rear-View Mirror. Antipode 44 (3), 993-1014

Prashad, V. (2007) The darker nations: a people's history of the third world. New York: The New Press.

Ray, R., Gallagher, K., López, A., \& Sanborn, C. (Eds.). (2017). China and sustainable development in Latin America: the social and environmental dimension. Anthem Press.

Richey, L.A., Ponte, S. (2014). New actors and alliances in development. Third World Quarterly 35(1): 1-21.

Rist, G. (1997) The History of Development: From Western Origins to Global Faith. London \& New York: Zed Books

Rodrigues, MGM (2016) The prospects for transnational advocacy across the IBSA bloc - a view from Brazil. Third World Quarterly, 37 (4), 703-20.

Rowden, R. (2011) 'India's role in the new global farmland grab.' GRAIN and Economics Research Foundation: New Delhi.

http://www.macroscan.org/anl/aug11/pdf/Rick_Rowden.pdf (last accessed August 30, 2016).

Sautman, B. and Hairong, Y. (2016) The discourse of racialization of labour and Chinese enterprises in Africa. Ethnic and Racial Studies 39 (12): 2149-2168. 
Saxena, P. (2016) India's Lines of Credit: instrument of economic diplomacy. In S.

Chaturvedi and A. Mulakala (eds.) India's Approach to Development Cooperation. Routledge Contemporary South Asia Series. London and New York: Routledge.

Schmidt-Traub G (2015) Investment Needs to Achieve the Sustainable Development Goals: Understanding the Billions and Trillions. http://unsdsn.org/wpcontent/uploads/2015/09/151112-SDG-Financing-Needs.pdf

Scoones, I., Amanor, K., Favareto, A. and Qi, G. (2016) 'A new politics of development cooperation? Chinese and Brazilian engagements in African agriculture.' World Development 81, pp. 1-12.

Severino J-M and Ray O, 2009: The end of ODA: death and rebirth of a global public policy, Working Paper no. 167. Washington DC: Center for Global Development.

Shankland, A. and Gonçalves, E. (2016) 'Imagining agricultural development in south-south cooperation: The contestation and transformation of ProSAVANA.' World Development 81: $35-46$.

Sidiropoulos, E., Pineda, J., Chaturverdi, S., Fues, T. (2015) Institutional Architecture \& Development: Responses from emerging powers. South African Institute of International Affairs: Johannesburg

Six, C. 2009: The rise of postcolonial states as donors: a challenge to the development paradigm?' Third World Quarterly, 30 (6), 1103-1121

Stahl, Anna K.., "Fostering African Development, Governance and Security through Multilateral Cooperation between China and Western Donors: The Case of the China-DAC Study Group", in Mulugeta Gebrehiwot Berhe and Liu Hongwu (eds.), China-Africa Relations: Governance, Peace and Security, Institute for Peace and Security Studies (IPSS) of Addis Ababa University and the Institute of African Studies (IAS) of the Zhejiang Normal University (ZNU), 2013, pp. 74-96. 
Suyama, B., Waisbich, L.T., and Leite, I.C. (2016) Brazil as a Development Partner under Lula and Dilma: Shifts and continuities. In J. Gu, A. Shankland, A. Chenoy and R. Carey (eds) The BRICS in International Development. Palgrave Macmillan, pp. 25-62.

Taela, K. (2016) 'History and Political Imaginaries: Brazilian Development Workers and Mozambique', paper presented at the Development Studies Association Conference, University of Oxford, 12-14 September.

Tang, L., Zhao, W., Mukwereza, L. and Li, X. (2015) 'Mixed starts and uncertain futures: Case studies of three Chinese agricultural investments in Zimbabwe.' Future Agricultures Working Paper 125.

https://opendocs.ids.ac.uk/opendocs/bitstream/handle/123456789/7092/FAC_Working_Pape r_125.pdf? sequence=1 (last accessed August 30, 2016).

Taylor, I. (2016) Dependency Redux: why Africa is not rising. Review of African Political Economy, 43: 8-25.

Tugendhat, H. and Alemu, D. (2016) Chinese Agricultural Training Courses for African Officials: Between Power and Partnerships. World Development, 81: 71-81.

UNDP 2013: Human Development Report: The Rise of the South - Human Progress in a Diverse World, New York: UNDP

van der Merwe, J., I. Taylor, and A. Arkhangelskaya, (eds) (2016) Emerging Powers in Africa: A New Wave in the Relationship? London: Palgrave Macmillan.

Verhoeven, H. (2014) 'Is Beijing's non-Interference policy history? How Africa is changing China.' The Washington Quarterly 37(2): 55-70.

Vittorini, S. (2015) A Nehru-lite Third India-Africa Forum Summit. Presentation at SSAI Panel Discussion. Available at https://www.soas.ac.uk/south-asiainstitute/events/file108671.pdf 
Woolford, W. and Nehring, R. (2015) Constructing parallels: Brazilian expertise and the commodification of land, labour and money in Mozambique. Canadian Journal of Development Studies / Revue canadienne d'études du développement, 36 (2), 208-223

Xu, X., Li, X., Qi, G., Tang, L. and Mukwereza, L. (2016) 'Science, technology, and the politics of knowledge: The case of China's agricultural technology demonstration centers in Africa.' World Development 81: 82-91.

Zerba, S.H. (2014) 'China's Libya Evacuation Operation: a new diplomatic imperative overseas citizen protection.' Journal of Contemporary China 23 (90): 1093-1112. 